\title{
INTERNATIONAL ASSOCIATION for the Physical Sciences of the Oceans (IAPSO), Commission on Natural Marine Hazards
}

\author{
By M.I. El-Sabh
}

Natural and man-made hazards such as tropical cyclones, floods, storm surges, tsunamis, severe waves, red tides, earthquakes, environmental pollution, volcanic eruptions, and chemical pollution present global challenges that know no national or international boundaries and therefore present challenging and life-threatening problems to all the people of the world. In fact, unless conscious and dedicated efforts by all nations are developed and implemented. the lives and the quality of all people on earth are seriously and irreparably threatened.

In December 1987, the United General Assembly adopted resolution $42 / 169$ to designate the 1990s as a decade in which the international community. under the auspices of the United Nations, will pay special attention to fostering international cooperation in the field of natural disaster reduction.

The objective of this decade is to reduce. through concerted international actions, especially in developing countries. loss of life, property damage and social and economic disruption caused by natural disasters.

Geological and geophysical natural hazards, such as earthquakes and volcanoes. are the concern of the International Association of Seismology and Physics of the Earth's Interior (IASPEI) and the International Association of Volcanology and Chemistry of the Earth's Interior (IAVCEI). Meteorological hazards are under the aegis of the International Association of Meteorology and Atmosphere Physics (IAMAP). However, natural marine hazards have not received similar attention; to correct this shortcoming, an IAPSO Commission of Natural Marine Hazards (NMH) was established recently.

The terms of references for the commission are:

- To support and interact with other

M.I. El-Sabh. President. Nuthral Hazards Society 310. Allée des Urisulines. Rumouski, Québec Canada G5L $3 A I$. bodies interested in natural marine hazards,

- To encourage scientific research in all types of natural and man-made marine hazards in order to provide basic knowledge and understanding on the causes and ramifications of such hazards on the quality of human lives.

- To convene working groups and regular international conferences,

- To encourage the exchange of scientific results and to provide a forum for the open discussion of pertinent subject matter of international interest, concern and significance, and

- To formulate scientific consensus regarding mitigation of such hazards.

The resolution was adopted on August 23, 1988, during the IAPSO Executive Committee meeting held in Acapulco. Mexico.

Mohammed I. El-Sabh was nominated as the President of the NMH Commission.

\section{Natural Hazards Society (NHS) Founded}

\section{By M.I. El-Sabh}

A new International Society for the Prevention and Mitigation of Natural Hazards has been formed to promote research on all aspects of natural hazards, to promote the distribution of preparedness plans for all countries, and to formulate and implement education programs concerned with the mitigation of natural hazards.

The founding organizational meeting was held on August 17. 1988. in Ensenada, Mexico. At this meeting, which was attended by about 100 participants from fourteen countries, a constitution and bylaws for the society were adopted and the following officers were elected:

- President: M.I. El-Sabh (University of Québec. Rimouski, Québec, Canada).

- Vice-President: G. Pararas-Carayannis (International Tsunami Information Center, Honolulu, Hawaii, USA).

- Secretary: T.S. Murty (Institute of Ocean Sciences, Sidney, B.C.. Canada),

- Treasurer: S. Venkatesh (Atmospheric Environment Service. Downsview. Ont.. Canada),

- Representatives-at-Large: S.F. Farrerras (CICESE. Ensenada. Mexico); S.K. Ghosh (Indian Meteorol. Dept., New Delhi,
India); F.S. Liu (Academic Sinica, Qingdao, China).

The Society will hold international scientific meetings at least biennially, with special symposia on topical natural disaster events or natural hazard studies. In addition, the NHS will co-sponsor appropriate scientific meetings, summer schools, or workshops organized by other bodies. An official society journal. Natural Hazards: An International Journal of Hazards Research and Prevention, is published at regular intervals by Kluwer Academic Publishers in the Netherlands.

Membership of the NHS is open to all international scientists and policy makers actively engaged in natural hazard studies or the prevention and mitigation of natural disasters. Dues for 1988 are US $\$ 20$ per year for all individual members, US $\$ 5$ for students.

For general information about the society or membership inquiries and applications, write to one of the following:

M.I. El-Sabh, President, 310, Allée des Ursulines, Rimouski, Québec, Canada G5L 3A1:T.S. Murty, Secretary, P.O. Box 6000 , Sidney. B.C.. Canada V8L 4B2. 